\title{
Relationship between the Brand Identity with Brand Loyalty due to the Mediating Role of Perceived Value
}

\author{
Reza Abedi ${ }^{1}$, Fereydoon Azma ${ }^{1 *}$ \\ ${ }^{1}$ Department of Management, Aliabad Katoul Branch, Islamic Azad University, Aliabad Katoul, IRAN
}

*Corresponding Author: azmafereydoon@yahoo.com

Citation: Abedi, R. and Azma, F. (2019). Relationship between the Brand Identity with Brand Loyalty due to the Mediating Role of Perceived Value. Dutch Journal of Finance and Management, 3(1), em0059. https://doi.org/10.29333/djfm/5876

Published: June 15, 2019

\begin{abstract}
The aim of present study was to investigate the relationship between brand identity with brand loyalty regard to the mediating role of perceived value of the brand, brand trust, and customer satisfaction of brand. The research method was descriptive/monitoring -correlation type. The population was all customers of Sabah Dairy Company in Golestan province, Iran that 384 individuals were determined as the sample size and sampling was clustering method. The research tools were following questionnaires standard brand identity by "Bhattacharya and Sen", brand loyalty, brand trust and brand customer satisfaction by He et al., brand equity by Nam et al., standardized questionnaire of brand perceived value by Lasar et al. The reliability of the questionnaire using Cronbach's alpha coefficient were calculated 0.844, 0.815, 0.661, 0.859, 0.724 and 0.885 for brand identity, perceived value of the brand, brand customer satisfaction, brand trust, brand loyalty and brand equity, respectively and the validity of questionnaires was approved with convergent validity method. The results showed that there was significant relationship between the brand identity with brand loyalty due to the mediating role of perceived value, trust and satisfaction.
\end{abstract}

Keywords: brand identity, brand loyalty, brand equity, perceived value of the brand, brand trust, brand customer satisfaction

\section{INTRODUCTION}

Brand is one of the most valuable assets of any organization that the proper management can be a way to reach more market share and profitability in every industry. In the past literature on the topic of brand identity, it was not sufficient and adequately relationship consideration the brand loyalty and still there is no coherent framework for it. But recent researches have pointed to the relationship between the brand identity of consumer loyalty (Hi and $\mathrm{Li}, 2011)$ and a few researches were verified the comprehensive and holistic relationship with loyalty and brand identity (He et al., 2012). Brand identity is an enterprise factor that leads to improvement of brand equity (Burmann et al., 2009). Brand equity in both marketing and finance literature is discussed (Parker, 2005). Brand loyalty and positive feelings toward the brand are shaped by perceptions and leads to repeat purchase (Martineza et al., 2009).

Brand loyalty is one of the most important factors affecting on brand equity. There are conflicting views on the relationship between loyalty and brand equity. Many researchers believe both input and output of brand loyalty are equity of brand which addition to the dimensions of brand equity effective is affected on the sense of loyalty. It also is. In other words, loyalty and brand equity are mutually influenced on each other (Moisescu, 2006). In the present study the relationship between loyalty and brand equity was evaluated. Many studies have been done on brand equity, mostly external factors such as brand awareness, brand value, brand trust, satisfaction, brand loyalty, 
Table 1. The question distribution of the questionnaire

\begin{tabular}{|c|c|c|c|}
\hline Variable & Dimension & Number of Questions & Questions \\
\hline Brand identity & - & 3 & $1-3$ \\
\hline Perceived value of the brand & - & 3 & $4-6$ \\
\hline Brand customer satisfaction & - & 4 & $7-10$ \\
\hline Brand trust & - & 5 & $11-15$ \\
\hline Brand loyalty & - & 7 & $16-22$ \\
\hline \multirow{5}{*}{ Brand equity } & Physical quality of product & 4 & $23-26$ \\
\hline & Ideal self-adaptive & 3 & $27-29$ \\
\hline & Brand recognition and awareness & 5 & $30-34$ \\
\hline & Compliance with lifestyle & 3 & $35-37$ \\
\hline & Brand attachment & 3 & $38-40$ \\
\hline
\end{tabular}

and the verified quality (Kim and Hyun, 2011). Only some studies have been focused on equity brand with identity brand view - usually by staff and members of the firm- (Nam et al., 2011).

Today, the process of value creating was become one of the most important research topics in marketing. Generally, value in marketing is perceived value by customer that is covered both economic and non-economic components (Woodside et al., 2008). Based on this definition, it seems that the assessment is done only by the customer. The perceived value is strongly affected by the brand identity and appropriate brand identity has positive impact on the perception of the brand identity. A brand with a strong identity symbolic will solved more requests of customers compared to their applicable needs (He et al., 2012). The results of researches show that the stronger brand identity leads to more power to increase the perceived value (Parasuraman and Grewal, 2000). According to researches, features such as global brand and its reputation (which all goes to his identity), has positively related to brand equity and it increase the brand value (especially economic brand value). Thus, the present study seeks to answer the question whether is any relation between the brand identity and brand loyalty due to the mediating role of perceived value of the brand, brand trust for customer satisfaction of dairy brand of Sabah.

\section{METHODOLOGY}

The research method was descriptive and correlation type. The population was all customers of Sabah dairy products in the Golestan province. Due to large number of Sabah products consumers in the Golestan province and there was no possibility to list them and randomized sampling, cluster sampling method was used. This means that all the stores in Golestan province that sold Sabah products were listed and several shops were selected randomly among them. Then, among selected stores, questions were randomly asked from people who had consumed Sabah products that ultimately, 384 individuals were selected based on Morgan table that 422 questionnaires were and distributed among the participants and were collected.

The study was performed after describing in detail to participants the introductory remarks about the gauges and the purpose of the test, how to response to tests. It can be noted that regarding to ethical considerations, they were assured that the information will be used only in the research and be protected from any abuse after obtaining the consent of the people and giving the necessary knowledge.

In the present study, standardized questionnaire of Bhattacharya and Sen (2003) was used to measure the brand identity, this questionnaire had 3 questions. Standardized questionnaire of He et al. (2012) was used to evaluate the variables of brand loyalty, brand trust and brand customer satisfaction, these questionnaires had 7, 5 and 4 questions, respectively.

Also, standardized questionnaire of Nam et al. (2011) was used to measure the variable of brand equity that this questionnaire has 18 questions, and standardized questionnaire of Lasar et al. (1995) was used to measure the perceived value of the brand (quoted by from Ebrahimi et al., 2012) that this questionnaire includes 3 questions. Structure of used questionnaires was according to the Table 1.

Validity of questionnaires was confirmed by professors and experts. To evaluate the reliability, questionnaires were distributed to 30 individuals and reliability of the questionnaires were calculated using Cronbach's alpha, which is described in Table 2. 
Dutch Journal of Finance and Management, 3(1), em0059

Table 2. Cronbach's alpha coefficient of research variables

\begin{tabular}{lcc}
\hline Variable & Number of Questions & Cronbach's alpha coefficient \\
\hline Brand identity & 3 & 0.844 \\
\hline Perceived value of the brand & 3 & 0.815 \\
\hline Brand customer satisfaction & 4 & 0.661 \\
\hline Brand trust & 5 & 0.859 \\
\hline Brand loyalty & 7 & 0.724 \\
\hline Brand equity & 18 & 0.885 \\
\hline
\end{tabular}

Structural equation modeling was used to analyze the data

Table 3. The results of direct correlation and significant coefficients

\begin{tabular}{lcccc}
\hline Hypothesis & Sign & Path coefficient & Absolute value of t statistic & Test results \\
\hline Perceived value of the brand <- Brand identity & $\mathrm{BI} \rightarrow \mathrm{PV}$ & 0.798 & 6.027 & Confirmed \\
\hline Brand trust <- Brand identity & $\mathrm{BI} \rightarrow \mathrm{BT}$ & 0.617 & 3.926 & Confirmed \\
\hline Brand customer satisfaction $<-$ Brand Identity & $\mathrm{BI} \rightarrow \mathrm{CS}$ & 0.593 & 3.595 & Confirmed \\
\hline Brand trust <- Perceived value of the brand & $\mathrm{PV} \rightarrow \mathrm{BT}$ & 0.672 & 4.682 & Confirmed \\
\hline Brand trust <- Customer satisfaction Brand & $\mathrm{CS} \rightarrow \mathrm{BT}$ & 0.723 & 4.524 & Confirmed \\
\hline Brand loyalty $<-$ Brand trust & $\mathrm{BT} \rightarrow \mathrm{BL}$ & 0.768 & 5.986 & Confirmed \\
\hline Brand equity $<-$ Brand loyalty & $\mathrm{BL} \rightarrow \mathrm{BE}$ & 0.659 & 4.156 & Confirmed \\
\hline
\end{tabular}

Table 4. The relationship between the variables in the main model of research

\begin{tabular}{lccc}
\hline The relationship & Direct relationship & Indirect relationship & Total relationship \\
\hline $\begin{array}{l}\text { Brand identity and brand loyalty through } \\
\text { perceived value, brand customer }\end{array}$ & 0.510 & $0.798 \times 0.643=0.513$ & \\
satisfaction and brand trust & & $0.617 \times 0.768=0.473$ & 1.99 \\
\hline
\end{tabular}

\section{RESULTS}

The results are presented in Tables 3 and 4. According to Table 3, it can be said that path coefficient between brand identity and perceived value of the brand was 0.798 . T statistic was obtained 6.027 for this coefficient, and its value was significantly higher than the threshold of 1.96. Therefore, there was significant relationship between brand identities with perceived value of brand. The path coefficient was achieved 0.617 between brand identity and brand trust.

T statistic was 3.926 for this coefficients and its value was obtained significantly higher screw threshold of 1.96. Therefore, there was significant relationship between the brand identity and brand trust. The path coefficient was 0.593 between brand identity and brand customer satisfaction. T statistic was 3.595 for this coefficient and its value was obtained significantly higher screw threshold of 1.96.

Therefore, there was significant relationship between the brand identities with brand customer's satisfaction. The path coefficient between perceived value of the brand and brand trust was 0.672. T statistic was 4.682 for this coefficient, its value was obtained significantly higher screw threshold of 1.96. Therefore, there was significant relationship between the perceived value of the brand and brand trust. The path coefficient between brand customer satisfaction and brand trust was 0.723 . T statistic was 4.524 for this coefficient; its value was obtained significantly higher than threshold of 1.96. Therefore, there was significant relationship between customer satisfaction and brand trust.

The path coefficient between brand trust brand and brand loyalty was 0.768 . T statistic was 5.986 for this coefficient; its value was obtained significantly higher than threshold of 1.96. Therefore, there was significant relationship between customer satisfaction and brand trust.

The results of Table 4 shows that the path coefficient between brand identity and brand loyalty was 0.510 and the value for this coefficient was 2.951, while the indirect correlation with perceived value, trust and satisfaction was estimated $0.473,0.513$ and 0.494 , respectively that the total relationship will reach to 1.99 . This showed that perceived value, trust and satisfaction variables were in the relationship between brand identity with and brand loyalty. So, it can be concluded that there was significant relationship between brand identity and brand loyalty due to the mediating role of perceived value, trust and satisfaction.

\section{CONCLUSION}

The aim of this study was to investigate the relationship between brand identity with brand loyalty regard to the mediating role of perceived value of the brand, brand trust, and customer satisfaction of brand. The results 
showed that there was significant and positive relationship between brand identities with perceived value of brand. Namely, to increase brand identity, perceived value of brand increases, as well.

In other words, the perceived value of the brand is heavily influenced by the brand identity and brand appropriate identity impact positively on the perceived value of the brand. The results of this hypothesis was in line with the findings of Ahmadi et al. (2014), Hosseini et al. (2011), Khojeh (2014), Mohammadi (2013), Dehdashti-sharokh et al. (2012) and He et al. (2012). The results of present study indicated that a stronger brand identity leads to more power to increase the perceived value. Results of other studies also follow this claim. According to research, a feature such as global brand and its reputation (which all goes to his identity) has positive relationship with brand equity and increases brand value (especially brand economic value).

The results of the study revealed that there was significant and positive correlation between brand identity and brand trust. Namely to increase brand identity, brand trust increases. The results of this hypothesis was in line with the findings of Ahmadi et al. (2014), Hosseini et al. (2011), Khojeh (2014), Mirzaee (2013), Dehdashti-sharokh et al. (2012) and He et al. (2012).

But it was not in line with the results of Mohammadi (2013) because it was not found significant relationship between brand identity and brand trust. Some research results shows that reputation and well-known brands are likely benefit from higher trust of their customers. Brand reputation also helps greatly to its identity. Conducted researches in the field of brand identity shows a strong brand identity will have more confidence among consumers. Based on the research findings, there was a significant positive relationship between the brand identities with brand customer's satisfaction. Namely, to increase brand identity, brand customer satisfaction increases. On the other hand, if brand is much more familiar, the feeling of showing off and more satisfaction is created among customer. Hence, the distinct brand identity, the brand customer satisfaction is much.

The results of this hypothesis was in line with the findings of Ahmadi et al. (2014), Hosseini et al. (2011), Khojeh (2014), Mohammadi (2013), Mirzaee (2013), Dehdashti-sharokh et al. (2012) and He et al. (2012). The results of this study also confirmed a positive relationship between brand identity and satisfaction. Regard to the results, there was a significant and positive relationship between perceived value of the brand and brand trust. Namely, by increasing the perceived value of the brand, brand trust increases. The results of this hypothesis was in line with the findings of Ahmadi et al. (2014), Hosseini et al. (2011), Khojeh (2014), Mohammadi (2013), Shirazi et al. (2013), Dehdashti-sharokh et al. (2012), Ahmad et al. (2014), He et al. (2012) and Anderson and Srinivasan (2003).

As mentioned previously, customer perception of brand value is a function of their subjective perceptions and a single brand has different values in people view. Companies should discover criteria that lead to provide valued brand from the perspective of customers and respond appropriately to their needs. However, in recent years, the concept of perceived value has been the focus of many studies, but in this field, few studies have been done on the relationship between perceived value and theoretical support trust. Based on the findings, there was a significant and positive relationship between satisfaction of customers from brand and brand trust. It means, by increasing customer satisfaction, brand trust increases. So, it can be said that the satisfaction is the introduction of trust and provide the necessary preparations to build trust. Many researchers have evaluated the influence of satisfaction to create trust. The results of this hypothesis was in line with the findings of Ahmadi et al. (2014), Hosseini et al. (2011), Khojeh (2014), Mohammadi (2013), Dehdashti-sharokh et al. (2012) and He et al. (2012). Customer satisfaction brings favorable outcomes such as, cooperation, long-term willingness to company, loyalty and commitment to dependence.

Sichman (2007) showed that the majority of satisfied buyers are those who have established long-term relationships with brand, and satisfaction, trust and commitment lead to long-term relationships of supplier and buyer. According to the results, officials should increase more power and their focus on increasing the value of their product among consumers and with adherence to promises to consumer increase the trust of product demand over their brand. Indeed, according to the results, the high cost of advertising in order to visualize and increase brand reputation and trust are not recommended regardless of factors such as the perceived value of the brand and brand trust and other possible factors. The brand trust is safe feeling about offering customer products as well as customer confidence in the company's capabilities in delivering products, so, due to the large number of competition and brands multiplicity in dairy products to have reliable brand, facilitate the purchase process largely and create customer satisfaction. 


\section{REFERENCES}

Ahmadi, P., Jafarzadeh-kenari, M. and Bkhshizadeh, A. R. (2014). Glance at brand identity and its impact on brand loyalty and brand equity (case study: dairy and meat products company of Kaleh). Quarterly Journal of Commerce, (71).

Anderson, R. E. and Srinivasan, S. S. (2003). E-satisfaction and e-loyalty: A contingency framework, Psychology and Marketing, 20 (2): 99-121. https://doi.org/10.1002/mar.10063

Bhattacharya, C. B. and Sen, S. (2003). Consumer-company identification: A framework for understanding consumers' relationships with companies. Journal of Marketing, 67(2), 76-88. https://doi.org/10.1509/jmkg.67.2.76.18609

Burmann, C., Jost-Benz, M. and Riley, N. (2009). Towards an identity-based brand equity model. Journal of Business Research, 62, 390-397. https://doi.org/10.1016/j.jbusres.2008.06.009

Dehdashti Shahrokh, Z., Jafarzadeh-kenari, M. and Bkhshizadeh, A. R. (2012). Investigating the point of view of brand social identity and its impact on the development of brand loyalty (case study: dairy and meat products company of Kaleh). Journal of Modern Marketing Research, 2(2). https://doi.org/10.5267/j.msl.2012.03.020

Ebrahimi, A., Khalifeh, M. and Samizadeh, M. (2012). The effect of psychological processes on brand identity and brand personality on brand loyalty, scope of business management, (12).

$\mathrm{He}, \mathrm{H}$. and Li, Y. (2011). CSR and service brand: the mediating effect of brand identification and moderating effect of service quality. Journal of Business Ethics, 100(4), 673-688. https://doi.org/10.1007/s10551-010-0703-y

He, H., Li, Y. and Harris, L. (2012). Social identity perspective on brand loyalty. Journal of Business Research, 65(5), 648-657. https:// doi.org/10.1016/j.jbusres.2011.03.007

Hosseini, M. H. and Rezaei, M. (2011). Factors influencing brand loyalty in the dairy products market, business prospects, (5).

Khojeh, I. (2014). The point of view of brand social identity and its impact on the development of brand loyalty (case study: Irancell company in Golestan Province), M.A. thesis, Faculty of Management and Accounting, PNU Tehran.

Kim, J. H. and Hyun, Y. J. (2011). A model to investigate the influence of marketing-mix efforts and corporate image on brand equity in IT software sector. Industrial Marketing Management, 40, 424-438. https://doi.org/10.1016/j.indmarman.2010.06.024

Martineza, E., Montanerb, T. and Pina, J. M. (2009). Brand extension feedback: The role of advertising. Journal of Business Research, 62, 305-313. https://doi.org/10.1016/j.jbusres.2008.05.009

Mirzaee, F. (2013). The relationship between brand identity with brand loyalty in the mobile phone market. The International Conference on Management, Challenges and Solutions.

Mohammad, E. (2013). The effect of brand identity, customer loyalty of Samsung home appliances, M.A. thesis, Faculty of Management, Islamic Azad University of Tehran.

Moisescu, O. I. (2006). A conceptual analysis of brand loyalty as core dimension of brand equity, Published in: Competitiveness and Stability in the Knowledge-Based Economy No. International conference proceedings, Craiova, Romania, 1128-1136.

Nam, J., Ekinci, Y. and Whyatt, G. (2011). Brand equity, brand loyalty and consumer satisfaction. Annals of tourism research, 38(3), 1009-1030. https://doi.org/10.1016/j.annals.2011.01.015

Parasuraman, A. and Grewal, D. (2000). The impact of technology on the quality-value-loyalty Chain: A research agenda. Journal of the Academy of Marketing Science, 28(1), 168-174. https://doi.org/10.1177/0092070300281015

Parker, T. B. (2005). This brand's for me: brand personality and user imagery based self-congruity, Published Doctoral Disertation, University of Florida.

Woodside, A. G., Golfetto, F. and Gibbert, M. (2008). Customer value: theory, research, and practice, creating and managing superior customer value, Advances in Business Marketing and Purchasing, 14, Journal AI Press, Bodmin, 3-25. https://doi.org/10.1016/S1069-0964(08)14001-7 